\title{
Morphology of the Raised Shore Platforms along the Coastline between Daghmar and Dhabab, Sultanate of Oman
}

\author{
Salim Mubarak Al Hatrushi \\ Associate Professor \\ Geography Department \\ College of Arts and Social Sciences \\ Sultan Qaboos University \\ hatrushi@squ.edu.om
}




\title{
Morphology of the Raised Shore Platforms along the Coastline between Daghmar and Dhabab, Sultanate of Oman
}

\author{
Salim Mubarak Al Hatrushi
}

Abstract:

Raised shore platforms are rocky surfaces formed by wave action and subaerial weathering during global high sea level stands. The present height of the raised shore platforms is attributed to several factors, mainly to eustatic sea level changes, isostatic changes in the relative level of land and sea, and vertical tectonic activities. The aim of this study is to investigate the detailed morphology of the raised shore platform along the rocky coastline between Daghmar and Dhabab, in the southeastern part of Muscat Governorate. The study also intends to establish a tentative chronology of the raised shore platforms development. The methodology is based on field observation and documentation, along with satellite and aerial photographs analysis.

The results have shown that the study area has a sequence of five successive, well developed raised shore platforms that are well preserved, except the platform at $10 \mathrm{~m}$ altitude which is only found in isolated fragments. The formation of the raised shore platforms has been affected by a number of constructive factors including tectonic activity, and destructive factors such as fluvial action and subaerial weathering. No absolute dating has been reported or can be obtained from the study area, due to its erosional nature. However, dating from the shorelines adjacent to the study area, ranging in heights from 3 to $15 \mathrm{~m}$ above sea level, revealed a narrow range of 26,400 to 29,600 years. This period coincides with the last glaciations when the sea level was at about $75 \mathrm{~m}$ below the present level, and thus did not match with the altitudes of the platforms. This suggests that the platforms could belong to the last interglacial high sea level, when the sea level stood at about $6 \mathrm{~m}$ above the present level. Based on this scenario, the study concludes that the coastline of the study area has not experienced any significant uplift during the Late Quaternary.

Keywords: raise shore platform- tectonic uplift- sea level change- Oman coastline.

\section{مورفولوجية أرصفة النحت البحري المرفوعة على طول الشريط الساحلي بين دغمر وضباب، سلطنة عمان}

سالم بن مبارك الحتروشي

الملخص:

أرصفة النحت البحري عبارة عن أسطح صخرية شكلتها حركة الأمواج والتجوية خلال الفترات التي كان فيها مستوى سطح البحر عاليا.

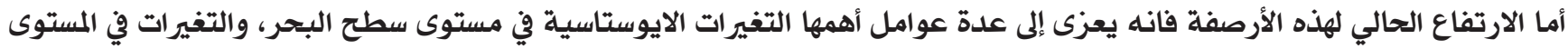

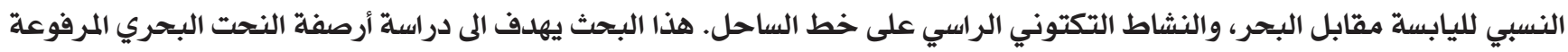
في الساحل الصخري الممتد بين دغمر وضباب، في الجزء الجنوبي الشرقي من محافظة مسقط. وتعتزم الدراسة، أيضا، وضع تسلسل زمسني لنشأة وتطور هذه الأرصفة. وتقوم منهجية الدراسة على الملاحظة الميدانية ودراسة ما كتب عن هذه الظاهرة، الى جانب تحليل الصور الجوية والمرئيات الفضائية.

وقد أظهرت نتائج الدراسة أن المنطقة تمتاز بوحود خمسة مستويات متعاقبة من أرصفة النحت البحري المرفوعة، بارزة وواضحة بجاءلاء،

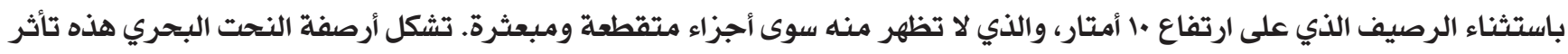

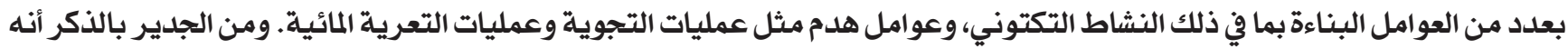

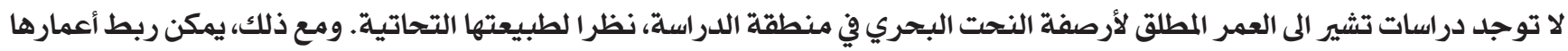

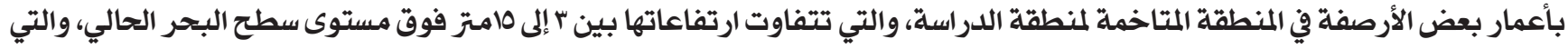

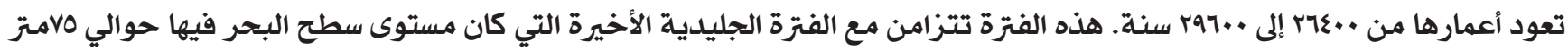
دون المستوى الحالي، وبالتالي فانه لا يوجد تطابق بين هذه الأعمار وارتفاعات هذه الأرصفة. وهذا يشير إلى أن هذه الأرصفة يمكن أن تعود إلى فترة ما بين الجليدين الأخيرين حين بلغ مستوى سطح البحر حوالي 7مـر فوق المستوى الحالي. وبناء على هذا السيناريو، فان الدراسية

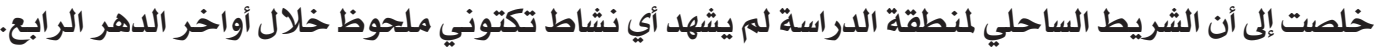
الكلمات المفتاحية: أرصفة النحت البحري المرفوعة، الرفع التكتوني، تغير مستوى سطح البحر، الساحل العماني. 


\section{Introduction}

Shore platforms are an intertidal rock surfaces developed on cliffed coasts. They extend from the high tide mark at the base of the cliff and slope gently seaward across the shore zone to the low tide mark. These features are also referred to as wave-cut platforms because they are formed primarily by mechanical wave action. However, this term is not preferred as it assumes that shore platforms are the result of wave action, which is not always true. Shore platforms are clearly erosional features formed primarily by mechanical wave action along with subaerial weathering, which weakens the cliff and prepares the weathered debris to be removed by wave and currents action (Trenhaile 1987 and Sunamura, 1992). On the other hand, the raised shore platforms are those rocky surfaces that were formed by wave action and subaerial weathering during global high sea level stands associated with the Late Cenozoic interglacial episodes.

The present height of the raised shore platforms is attributed to several factors but mainly to eustatic sea level changes, isostatic changes in the relative level of land and sea, and vertical tectonic crustal activities. The raised shore platforms provide evidence of higher sea levels in the geological past (Wilson et al. 1998) and have been used to identify areas of isostatic adjustment. By using scientific dating methods, or through examination of marine fossils found on the platform, it is possible to work out when the platform was formed, thus giving geographers and geologists information about sea levels at known times in the past. The raised shore platforms have been described by Pirazzoli (2005b) as a relatively flat, horizontal or gently inclined surface of marine origin which has been lifted out of the sphere of wave activity. It is often used for anthropogenic structures like settlements and infrastructure (Strahler, 2005). They have been studied in different parts of the world, especially coastal regions of tectonic activities.

Absolute sea level has been well below the present height for most of the last 120 thousand years, until the sea level returned to the present day values about ten thousand years ago. The sea level rose above the present height by a few meters at most, since the regression of the latest sea-level high stand, six thousand years ago (Lambeck et al., 2002).

The study area is part of Al Sharqiyah coastline, which stretches between Muscat and Ras Al Hadd. This rocky coastline is characterized by well-developed and successive raised shore platforms that show considerable variation in altitudes, suggesting tectonic uplift. Scientific research concerning the raised shore platforms in Al Sharqiyah coastline is limited. Glennie et al. (1974) reported a platform at a height of $300 \mathrm{~m}$ above mean sea level, which they believe may have been formed during the Late Miocene. Al-Hatrushi (1995) investigated the geomorphological evolution of the coastline between Muscat and Ras Al Hadd, in which he identified 12 different altitudes and grouped them into low-altitude (3-14m), medium altitude (20$58 \mathrm{~m})$ and high altitude $(85-260 \mathrm{~m})$. He attributed their height to tectonic uplift and their ages to Late Tertiary and Quaternary. Reyss et.al. (1998) investigated several sequences of Quaternary raised marine terraces along the south coast of Iran, from which they suggested a rate of uplift, along the south coast of Iran, at about $0.2 \mathrm{~mm} /$ year.

Hoffmann et.al. (2012a) have investigated the origin of the large blocks and boulders accumulated on the surface of platforms with heights up to 6 to $10 \mathrm{~m}$ above mean sea level. However, he interpreted their existence as tsunamigenic. Al Quraishi et al. (2012), Rupprechter. et al. (2012) and Hoffmann. et.al (2012b) described the Eastern coastline of Oman as an uplifted coastal area, characterized by raised wavecut terraces above present mean sea level. They believe that there is strong evidence of differential land movement along the coastline during the Late Cenozoic, locally indicated by marine terraces in elevations of up to $400 \mathrm{~m}$.

This paper aims to investigate the detailed morphology of the raised shore platform in the rocky coastal segment between Daghmar and Dhabab, in the southeastern part of Muscat Governorate. The study also intends to establish a tentative chronology of the raised shore platforms development. This paper is organized as follows: section 2 describes the datasets and methodology framework used to evaluate the mophostuctural analysis and the chronology of the raised platforms in the study area, section 3 details the geographical and geological setting of the study area, section 4 presents the obtained results. Finally, section 5 presents our conclusions.

\section{Datasets and methodology}

This paper deals with an application of geomorphological methods such as morph structural analysis, detailed geomorphological mapping based on filed observation and measurement using total station to survey the elevation and width of each raised shore platform by making several profile on each raised shore platform. High resolution satellite IKONOS im- 
ages, aerial photographs, and digital elevation model (DEM) from SRTM Images were used to measure and map the successive flights of raised shore platforms. Carbon 14 dating techniques were also used to retrieve the chronology of the raised platforms in the study area.

\section{Study area}

\subsection{Geographical setting}

The Omani coastline stretches for up to $3165 \mathrm{~km}$ in length including islands and embayments. It has large geomorphologic variations and can be classified as follows. In the north there is the ria coast of Musandam which is rocky with drowning wadis and embayments like the fjords of Norway, caused by very slow crust subduction. The Batinah coast is a wide flat sandy and shallow coast, created by alluvial fans. The Al Sharqiyah coast in the east is the steep and rocky with tidal inlets and pays and raised shore platforms. In the southeast is a sandy coast adjacent to Remal Al Sharqiyah (Wahiba Sands), and in the south is the steep cliffs coast of Dhofar that leaves some space in the middle for Salalah coastal plain to be developed. The coastline of Al Sharqiyah, including the study area, stretches approximately $200 \mathrm{~km}$ (excluding the length of the major embayments, which otherwise add to its total length) along the southeastern part of the Sea of Oman. It extends from Muscat in the northwest to Ras Al Hadd in the southeast (Figure 1) and It has predominantly rocky and irregular shores. According to the pathometric charts, the continental shelf is relatively narrow and the near shore topography is relatively steep. Furthermore, the Al Sharqiyah coastline is characterized by well-developed raised shore platforms, but they are not so well formed or they are absent elsewhere in Oman.

The study area, which is located in the southeastern part of Muscat Governorate, extends southeastward for approximately $9 \mathrm{~km}$, between the village of Daghmar Quriyat and the village of Dhabab (Figure 2). It is a rocky coastline that separates the Quriyat alluvial plain from Dhabab rocky coastal plain. It has been selected because it is unique and well defined geologically and geomorphologically. Lithologically, it is dominated by Tertiary dolomite cliffs and structurally it is situated between two major normal faults forming a major horst structure. Geomorphologically, the segment has a sequence of four successive and well developed and preserved staircase-like abrasion surfaces forming raised shore platforms with different altitudes of different ages, which can be well measured and mapped. At the extreme southern end of the segment, a remnant of a fifth platform is preserved in isolated locations where it underlies gravel terrace at about $10 \mathrm{~m}$ height.

There are no sand or gravel beaches developed in this coastline segment. It is a nearly vertical escarpment that rises abruptly from the sea bed. Wadi Hawir, which dissects the segment and the raised shore platforms at the centre, has created a deep and narrow gorge at the mouth of which Khawr Khuwayr lies. The gorge is about $200 \mathrm{~m}$ wide and is bounded by vertical walls that rise approximately $150 \mathrm{~m}$. At the mouth of the wadi, gravel beaches and mangrove stands have developed, but no alluvial plain.

\subsection{Geological setting}

Geologically, the coastline of Al Sharqiyah is part of Eastern Hajar of the North Oman Mountains. Ophiolite and limestone bedrock dominate the coastline between Muscat and Quriyat forming the most rugged and irregular coastline in the area. The other part of the coastline is dominated by tertiary dolomite and limestone cliffs, reaching a height exceeds $1000 \mathrm{~m}$, or low cliffs composed of Quaternary marine and terrestrial deposits. The cliffed coast forms the major structural components of the coastline, while sandy and gravel beaches make a minor component.

Structurally, the Sultanate of Oman borders the Indian Ocean and the Sea of Oman and is part of the Arabian Plate. The tectonically active, Owen Fracture Zone marks the boundary to the Indian Plate in the east (Figure 3). The Arabian Plate is further confined by active spreading axis in the Gulf of Aden and the Red Sea defining the Southern and the Southwestern boundary. The Makran and Zagross fold and thrust belts marks the northern boundary and are characterized by a continent - continent collision zone, that is the Makran Subduction Zone (MSZ) situated in the Sea of Oman (Hoffmann et.al. 2012a). On the other hand, numerous systems of major and minor faults dissect the coastline including the study area. The direction of these faults follows two systems; one parallel and the other perpendicular to the coastline (Figure 4).

\section{Results}

4.1. Geomorphology of the raised shore platforms The field work and surveying revealed that there is a sequence of five successive raised shore platforms, including the remnants of the $10 \mathrm{~m}$ high platform, prominent along the study coastline (Figures 5 and 6 ). The highest platform lies at an elevation of $+126 \mathrm{~m}$ above 
mean sea level. It is not well defined, its surface has been modified and destroyed by erosional processes caused by runoff, leaving a hummocky surface with extensive gullies. As so much of this platform has been modified, its width cannot be determined. The platform seaward cliff, however, is very prominent along the whole study coastline where it obtains a height of $30 \mathrm{~m}$.

The surface of the fourth platform, which reaches $+85 \mathrm{~m}$ above mean sea level, is also dissected by small and narrow dry gullies. Although it is relatively well defined and relatively wide ( $200 \mathrm{~m}$ ), its nearly flat surface has been modified by runoff, particularly in areas adjacent to the few existing drainage networks that exist, leaving a hummocky surface with extensive gullies. Its inland palaeo sea cliff which rises $30 \mathrm{~m}$ is well defined as well.

The second platform, which rises directly from the sea, lies at an altitude of $+20 \mathrm{~m}$ above mean sea level. Its surface starts relatively wide in the northwestern side near Quriyat where it obtains a width of nearly $200 \mathrm{~m}$ with a gentle seaward gradient of 4 degrees. The platform gets narrow southeastwards until it disappears near the first dry wadi that dissects the platforms at its northwestern part about $1.5 \mathrm{~km}$ southeast Daghmar. However, the surface of the platform appears again in the southeastern part of the study coastline, where it becomes relatively wide in a southeasterly direction. Its seaward cliff rises directly from the sea and attains an average elevation of $20 \mathrm{~m}$ above mean sea level. Its lower part is subjected to erosion by continuous wave action and subaerial weathering. The third platform lies at an altitude of $+51 \mathrm{~m}$ above mean sea level. It is well defined along the study coastline (Photo 1 ). Its surface attains an average width of $235 \mathrm{~m}$ with a seaward gradient of 4 degrees. Its seaward cliff rises some $51 \mathrm{~m}$ directly from the sea at the middle of the study area, where the lower platforms are absent because of erosion. However, its seaward cliff in other parts where the lower platforms existed is averaging $30 \mathrm{~m}$. Its inland cliff is also well developed, and rises $30 \mathrm{~m}$ high.

The remnants of the lower platform lie at an altitude of $10 \mathrm{~m}$ above mean sea level, and is only preserved at the southeastern part of the study coastline near Dhabab. They are found in isolated sites underlying eroded raised gravel terrace that measures $1-2 \mathrm{~m}$ in thickness. However, in other parts of the study coastline they are missing. Chemical weathering has been observed on the surfaces of the platforms as small scale karst topography in the form of small solution holes that reach $30 \mathrm{~cm}$ in diameter (Photo2).

The surfaces of the platforms are also affected by numerous systems of joints and fractures not exceeding $70-100 \mathrm{~cm}$ in length. The directions of these joints and fractures follow two systems; one parallel and the other perpendicular to the coastline. The surfaces of the platforms are covered mainly with blocks and boulders, the size of which is $70 \times 50 \times 50 \mathrm{~cm}$. However, these blocks and boulders are not considered by Hoffmann et.al. (2012a) who investigated large blocks and boulders accumulated on the surface of the platform with heights up to 6 to $10 \mathrm{~m}$ above mean sea level between Fins and Sur (further south), and who related their existence to tsunamigenic. However, the blocks that cover the surfaces of the platforms of the study area, with heights more than $20 \mathrm{~m}$ above mean sea level, are related to former wave action and subaerial weathering. It worth noting that, due to the erosional nature of the platforms surfaces, no marine sediments have been preserved on the surfaces of the platforms. The most striking issue in the morphology of the study area is the disappearance of the $+20 \mathrm{~m}$ level platform in the middle of the study area while, in other parts, it is still prominent. As stated earlier, this platform is relatively wide near Daghmar but it narrows down towards the southeast until it disappears near the first wadi gorge, and appears again beyond Khawr Khawyar in the southeast. Possibly, this platform might have been eroded completely. However, there is no evidence to support the first assumption because the platform is fairly well developed at both ends. The second assumption seems more likely because there are numerous vertical joints and fractures in the bedrock that form the platform cliff. These joints and fractures widened through time by wave action and subaerial weathering which, in turn, did result in the fall of large blocks from the active sea cliff. This argument suggests that the platform in the middle section formed a head land on which wave action was concentrated, and once the headland had receded and the coastline striated, wave action and erosion were reduced.

4.2. Chronology of the raised shore platform development in the study area

From the discussion above, it is clear that the formation of the raised shore platforms in the study area have been affected by a number of constructive and destructive factors. The most important constructive factors are eustatic sea level changes and geologic controls, including tectonic activity and displacement. On the other hand, the most important destructive 
Table 1: C14 dates of marine mollusks from sites in the adjacent coastline

\begin{tabular}{|c|c|c|c|c|c|c|c|}
\hline No & Locality & Lat ,long & Lab. No & Age(yrs BP) & Elev. $(\mathrm{m})$ & Dated materials & Ref \\
\hline 1 & Bir-Bira & $\begin{array}{l}59 \circ 27 \mathrm{E} \\
22 \circ 35^{\prime} \mathrm{N}\end{array}$ & $\begin{array}{c}\text { Hv16392 } \\
2304\end{array}$ & $5535 \pm 100$ & $\begin{array}{l}\text { c. } \\
2.5\end{array}$ & $\begin{array}{l}\text { Molluscs } \\
\text { (intertidal) }\end{array}$ & (a) \\
\hline 2 & Bir-Bira & $\begin{array}{l}59 \circ 27 \mathrm{E} \\
22 \circ 35^{\prime} \mathrm{N}\end{array}$ & $\begin{array}{c}\text { Hv16392 } \\
2381\end{array}$ & $4800 \pm 95$ & 2 & $\begin{array}{l}\text { Molluscs } \\
\text { (intertidal) }\end{array}$ & (a) \\
\hline 3 & Ras alHadd & $\begin{array}{l}59 \circ 47^{\prime} \mathrm{E} \\
22 \circ 32^{\prime} \mathrm{N}\end{array}$ & $\begin{array}{c}\text { Hv16388 } \\
2271\end{array}$ & $3305 \pm 90$ & 3 & Molluscs & (a) \\
\hline 4 & Quriyat & $\begin{array}{l}58 \circ 55^{\prime} \mathrm{E} \\
23 \circ 16^{\prime} \mathrm{N}\end{array}$ & $\begin{array}{c}\text { Hv13738 } \\
2092\end{array}$ & $3030 \pm 85$ & $\begin{array}{l}\text { c. } \\
2.5\end{array}$ & $\begin{array}{l}\text { Molluscs } \\
\text { (dunes) }\end{array}$ & (a) \\
\hline 5 & W.Ghalilah & $\begin{array}{l}59 \cdot 26^{\prime} \mathrm{E} \\
22 \cdot 37^{\prime} \mathrm{N}\end{array}$ & $\begin{array}{c}\text { Hv16389 } \\
2291\end{array}$ & $2605 \pm 85$ & 2 & Molluscs & (a) \\
\hline 6 & Bandar Gissa & $\begin{array}{l}58 \circ 39^{\prime} \mathrm{E} \\
23 \circ 33^{\prime} \mathrm{N}\end{array}$ & $\begin{array}{c}\text { Hv13738 } \\
2092\end{array}$ & $3450 \pm 90$ & 2.5 & Molluscs & (a) \\
\hline 7 & Ras al Hamra & $\begin{array}{l}58 \cdot 30^{\prime} \mathrm{E} \\
23 \cdot 38^{\prime} \mathrm{N}\end{array}$ & $\begin{array}{c}\text { Hv13743 } \\
2152\end{array}$ & $5960 \pm 100$ & 2.5 & Molluscs & (a) \\
\hline 8 & $6^{\sim}$ km SE Tiwi & $\begin{array}{l}59 \circ 15^{\prime} 55^{\prime \prime} \\
22 \circ 48^{\prime} 30^{\prime \prime}\end{array}$ & CAR-1552 & $27,600 \pm 650$ & 14 & coral & (b) \\
\hline 9 & $\begin{array}{c}\text { 300 m NW Makalla } \\
\text { Wabar }\end{array}$ & $\begin{array}{l}59 \circ 13^{\prime} 00^{\prime \prime} \\
22 \cdot 53^{\prime} 40^{\prime \prime}\end{array}$ & CAR-1553 & $29,600 \pm 800$ & 4.5 & $\begin{array}{l}\text { Bivalve and gas- } \\
\text { tropod }\end{array}$ & (b) \\
\hline 10 & $\begin{array}{c}\text { 7 km NW Sur(Bar- } \\
\text { Bira) }\end{array}$ & $\begin{array}{l}59 \circ 28^{\prime} 00^{\prime \prime} \\
22 \circ 36^{\prime} 50^{\prime \prime}\end{array}$ & CAR-1554 & $28,200 \pm 800$ & 4.5 & $\begin{array}{l}\text { Bivalve and gas- } \\
\text { tropod }\end{array}$ & (b) \\
\hline 11 & 3.5 km SW Dhabab & $\begin{array}{l}59 \circ 03^{\prime} 30^{\prime \prime} \\
23 \circ 03^{\prime} 15^{\prime \prime}\end{array}$ & CAR-1555 & $26,400 \pm 550$ 。 & 3 & $\begin{array}{c}\text { Bivalve and gas- } \\
\text { tropod }\end{array}$ & (b) \\
\hline
\end{tabular}

Ref. (a) Al-Hatrushi, 1995 and (b) Hannss, 1991

factors are fluvial action and subaerial weathering which modified the original morphology of the raised shore platforms.

Eustatic sea level change caused by climate change is the most important factor which shaped the study coastline. This factor is responsible for the formation and shaping the raised shore platforms. When the land emerged as a result of sea level drop during glaciations, or as a result of tectonic uplift, or a combination of both, the position of the shoreline moved seaward. Tectonic uplift is another important factor in forming these raised shore platforms which lie at heights far above the highest eustatic sea level record for the Quaternary and even the Pliocene. The highest platforms are believed to have been gradually uplifted since their formation during the Late Pliocene and Early Quaternary (Al-Hatrushi, 1995).

However, little is known about the ways in which these factors occurred and what changes they caused, because of the lack of previous detailed studies and the lack of absolute dating. Therefore, the tentative chronology of the raised shore platform development has been adapted.

\subsection{Determining the age of the platforms}

The raised shore platforms along the study area are erosional surfaces in nature. However, Holocene shorelines along the study coast are absent, either because they did not develop or they developed but were removed by wave action and weathering. This may explain why there is no dating in the studies which have been conducted in that area of the coastline. However, several authors, including Al-Hatrushi (1995) and Hannss (1991), reported dated beach deposits of Holocene and Late Pleistocene age (Table 1) along the Oman coastline adjacent to the study area. These dates were selected because they are relevant to this study.

The raised beaches reported by Hannss (1991), are characterized by heights between 2 to $3 \mathrm{~m}$ above mean sea level, and a minimum age of 3,000 years $B P$ and a maximum age of 5,500 years BP. These raised beaches are thought to have been formed during the Middle Holocene high sea level stand, and they correlate well with the Middle Holocene curve for the Persian Gulf as deduced by Pirazzoli (1991). Therefore, it can be suggested that the study coastlines adjacent to 
the study area have been tectonically stable and have experienced no significant crustal deformation during the past 5,000 years of the Holocene.

On the other hand, the five samples reported by AlHatrushi (1995) for shorelines ranging in heights from 3 to $15 \mathrm{~m}$ above sea level were in a narrow range of 26,400 to 29,600 years. However, according to the eustatic sea level curve of Shackleton (1987) for the Late Quaternary, this period coincides with the last glaciations (oxygen isotope stage 3 ) when the sea level was about $75 \mathrm{~m}$ below the present sea level, and thus these dates did not match with altitudes of the samples. This might be due to the fact that the samples are older and may have been contaminated. They could belong to the last interglacial high sea level, oxygen isotope stage 5 (125 ka BP) when sea level stood only at about $6 \mathrm{~m}$ above the present level. Accordingly, the coastline of the study area has experienced no significant uplift during the Late Quaternary. Unlike the south coast of Iran, on the other side of the Sea of Oman, which is located in a seismically active Zagros and Makran Provinces. According to Reyss et.al. (1998) the coastline experiences recent uplift at a rate of about $0.2 \mathrm{~mm} /$ year.

\section{Discussion and Conclusions}

Considering the tentative chronology of the raised shore platform development in the study area, it can be concluded that although Oman is situated close to major tectonically active zones (Owen Fracture Zone and Makran Subduction Zone) it is considered to have been in a comparatively stable segment of the earth crust, at least during the Late Quaternary. Furthermore, there is no clear evidence of tectonic activities, during the Late Quaternary, along the major and minor faults that dissect the study area.

Based on relative age, it is assumed that the low-altitude platform $(10 \mathrm{~m})$ of the study area may have been formed during the last interglacial high sea level. Consequently, medium altitude platforms (20m and $50 \mathrm{~m}$ ) could have been developed during the Middle Pleistocene. Accordingly, the higher platforms of the study area $(80 \mathrm{~m}$ and $120 \mathrm{~m})$ may have developed during the early stages of the Pleistocene. These assumptions are in agreement with those made by Glennie, et al (1974) that the platforms at the height of 300m above mean sea level been formed during the Late Miocene high sea level, Furthermore, since there is an ambiguity over the ages of the platforms of the study area, absolute dating evidence is needed to quantify the rate of uplift and to resolve crustal movement in time and space.

\section{References}

Al-Hatrushi, S.M. (1995), Morphology and Late Tertiary and Quaternary Evolution of the Oman Coastline Between Muscat and Ras al Hadd, Unpublished Ph.D. Thesis, University of Wales, Swansea (UK).

Al Quraishi, K. Al Balushi, N., Roepert, A., Rupprechter, M., and Hoffmann, G. (2012) " Late Quaternary delta evolution on an uplifted coastal area (Wadi Haida, Sultanate of Oman, Arabian Peninsula)" Abstract EGU 2012

Glennie, K. W. , Beouf, M. G., Hughes Clark, M. W., Moody-Stuart, M., Pilaar, W.F., and Reinhardt, B. M. (1974) "Geology of the Oman Mountains", Koningklijk Nederlands Geologisch en Mijnbouwkundig Genootschap, Transactions, vol. 31, part 1 (text), 423 pp.

Hannss, C. (1991) The Capital Area of Northern Oman, Teil 1, Basic Relief Development, Dr. Ludwigreichert Verlag, Wiesbaden, 117-124

Hoffmann, G. Reicherter, K., Wiatr, T., Grutzner, C. and Rausch, T. (2012a) "Blocks and Boulder accumulations along the coastline between Fins and Sur (Sultanate of Oman): Tsunamigenic remains?" Nat. Hazards, DOI 10.1007/s11069-012-0399-7, Springer

Hoffmann, G., Rupprechter, M., Roepert, A., Al Quraishi, K., Al Balushi, N., Grutzner, C.and Reicherter, K (2012b) "Quaternary coastal evolution of Oman (Arabian Peninsula) a quantitative approach" Abstract EGU 2012

Lambeck, K. , Esat, T.M.and Potter, E.K. (2002) "Links between climate and sea levels for the past three million years". Nature, 419, 199-206

Pirazzoli, PA (2005): 'Marine Terraces', in Schwartz, ML (ed) Encyclopedia of Coastal Science. Springer, Dordrecht, pp. 632-633

Reyss, J.I, Pirazzoli, PA, Haghipour, A., Hatte, C., \& Fontugne, M. (1998) "Quaternary marine terraces and tectonic uplift rates on the south coast of Iran" In. Stewart, I and Vita-Finzi, C (eds.) Coastal Tectonics. Geological Society, London. Special Publication No. 146. 225-237 
Rupprechter, M. Roepert, A. and Hoffmann, G. (2012) " Differential GPS measurements as a tool to quantify Late Cenozoic crustal deformation (Oman, Arabian Peninsula)" Abstract EGU 2012

Strahler AH; Strahler AN (2005): Physische Geographie. Ulmer, Stuttgart, 686 p.

Shackleton, N. J. (1987) “Oxygen isotopes, ice volume and sea level", Quaternary Science Reviews, 6: 183190

Trenhaile, A. S. 1987: The Geomorphology of Rock Coasts. (Oxford University Press, Oxford, U.K.) 393 pp.

Wilson, M.A., Curran, H.A. and White, B. 1998: Paleontological evidence of a brief global sea-level event during the last interglacial. Lethaia 31: 241-250

The Figures:

Figure (1): Location map of the Al Sharqiyah coastline

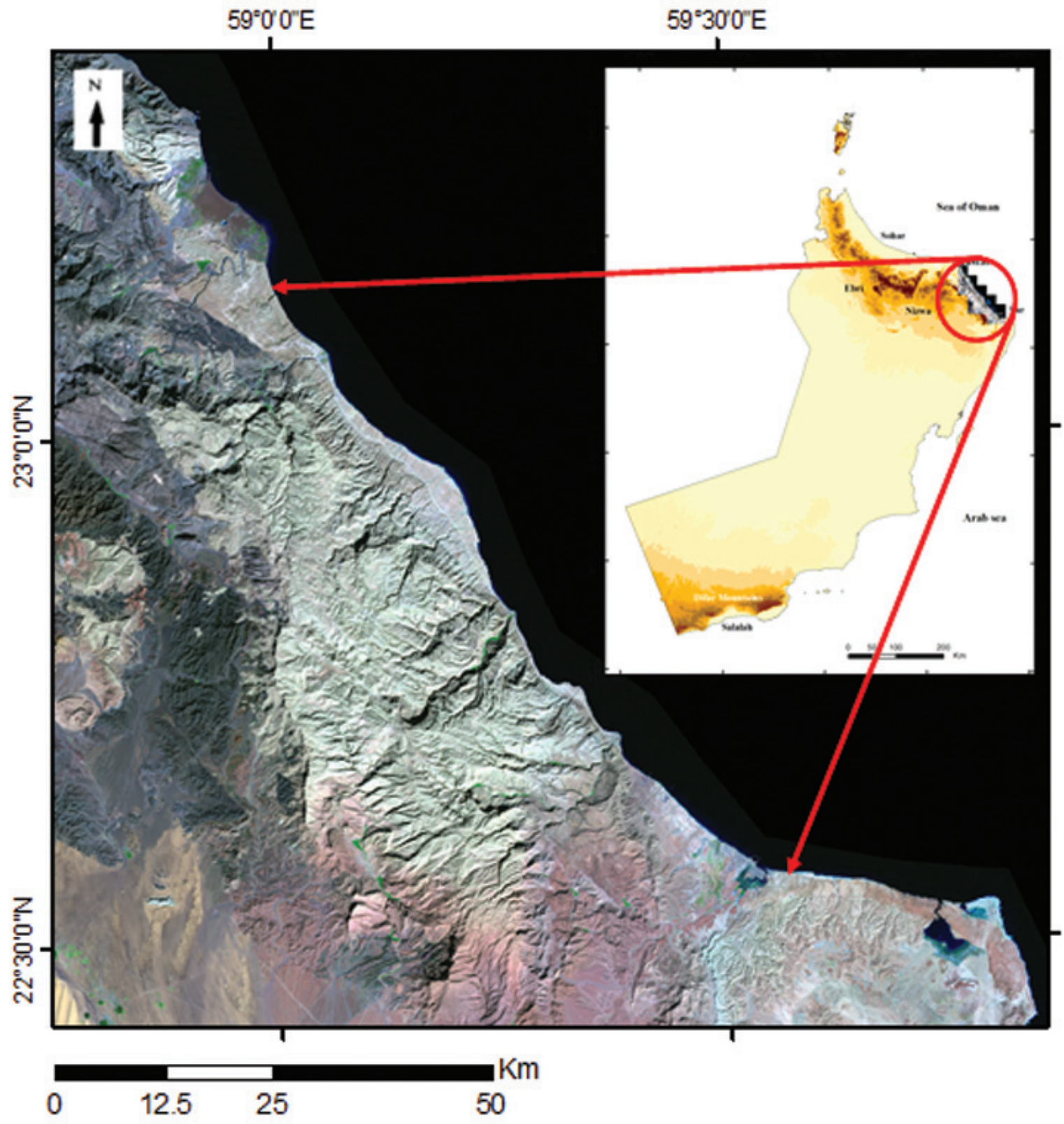


Figure (2) Study Area Map

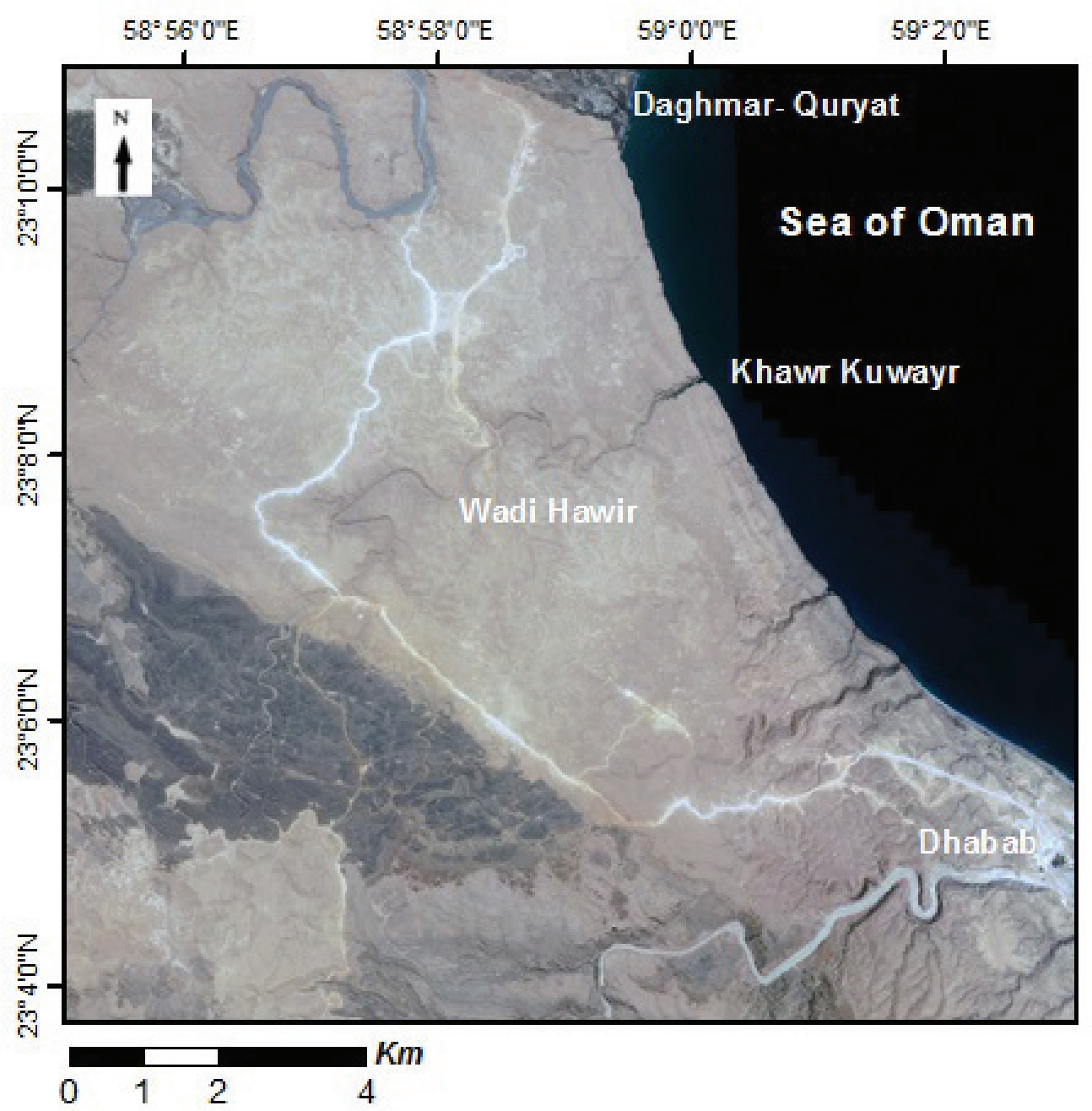

Figure (3): Plate Tetonic

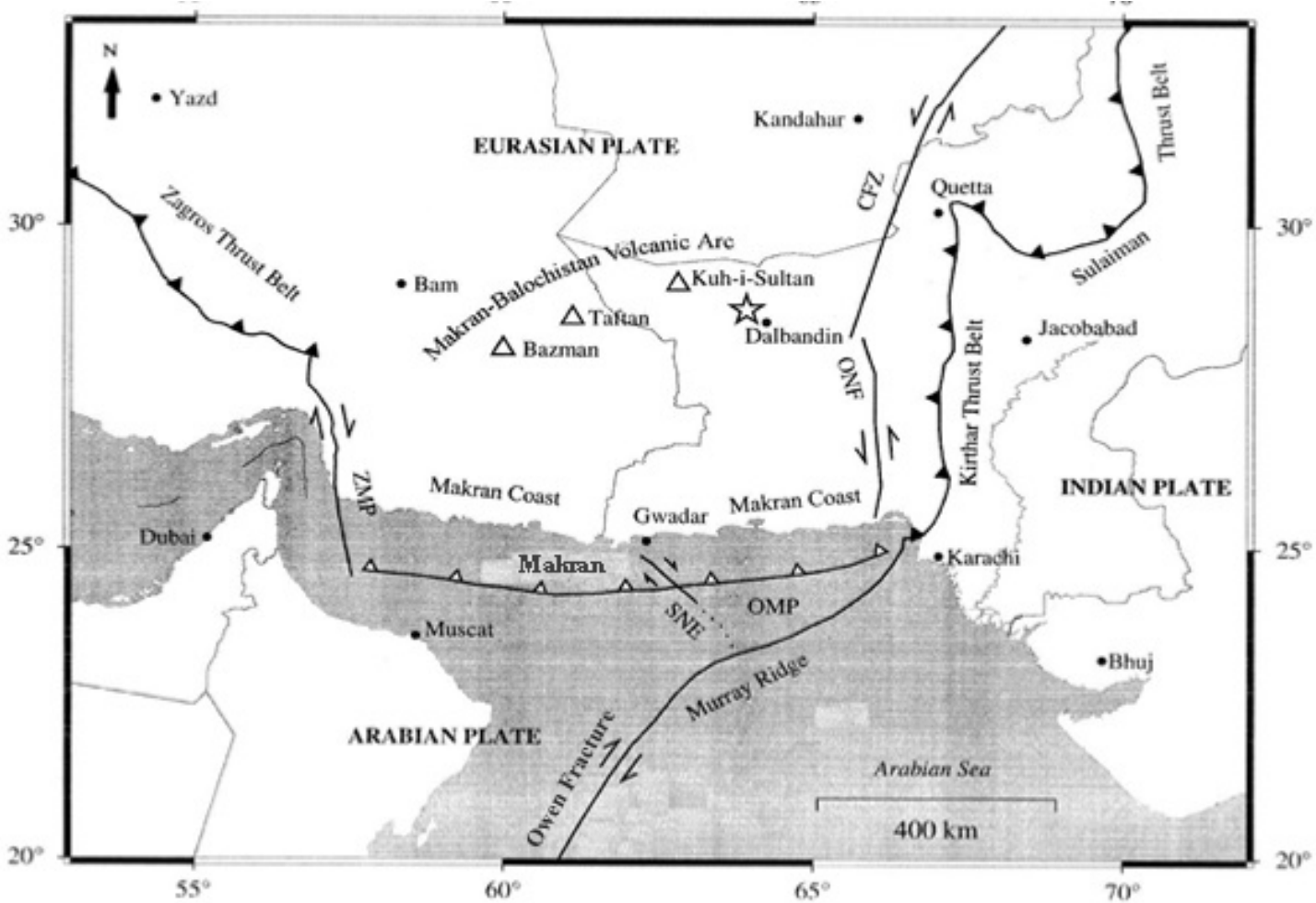


Figure (4): Structure and lithology map of the study area

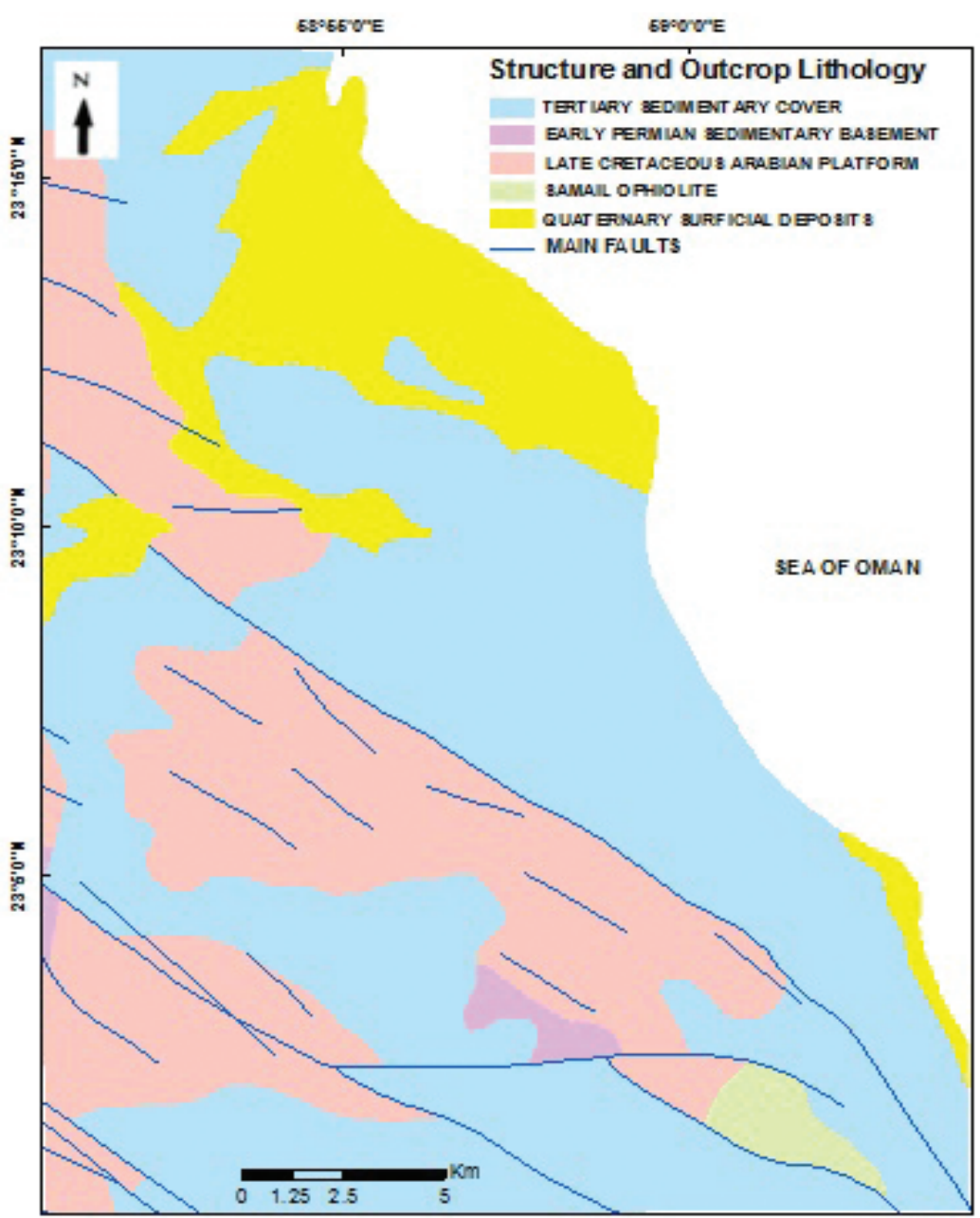

Figure (5): Geomorphologic map and shore platforms of the study area

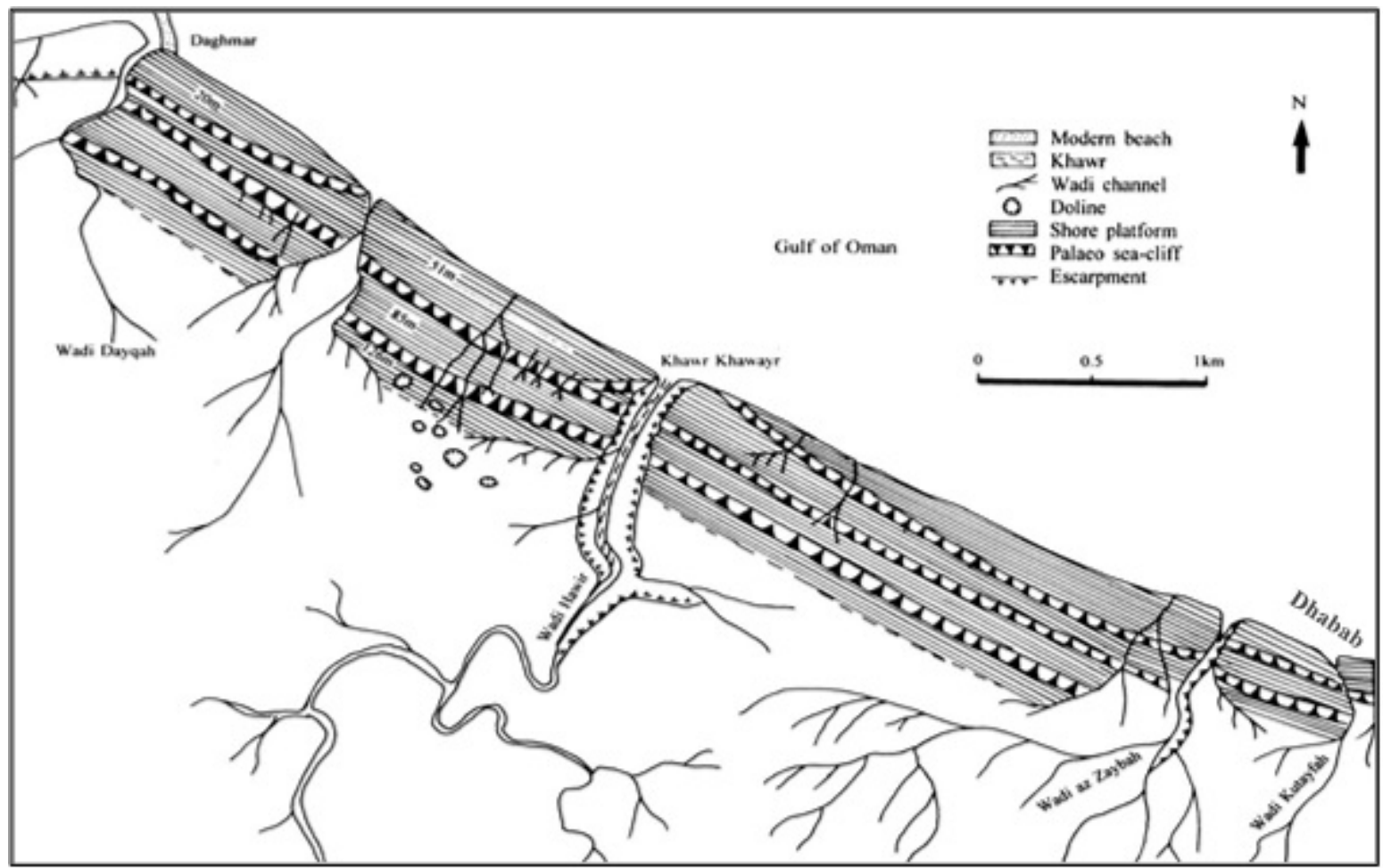


Figure (6): The relationship between the platforms and contour lines

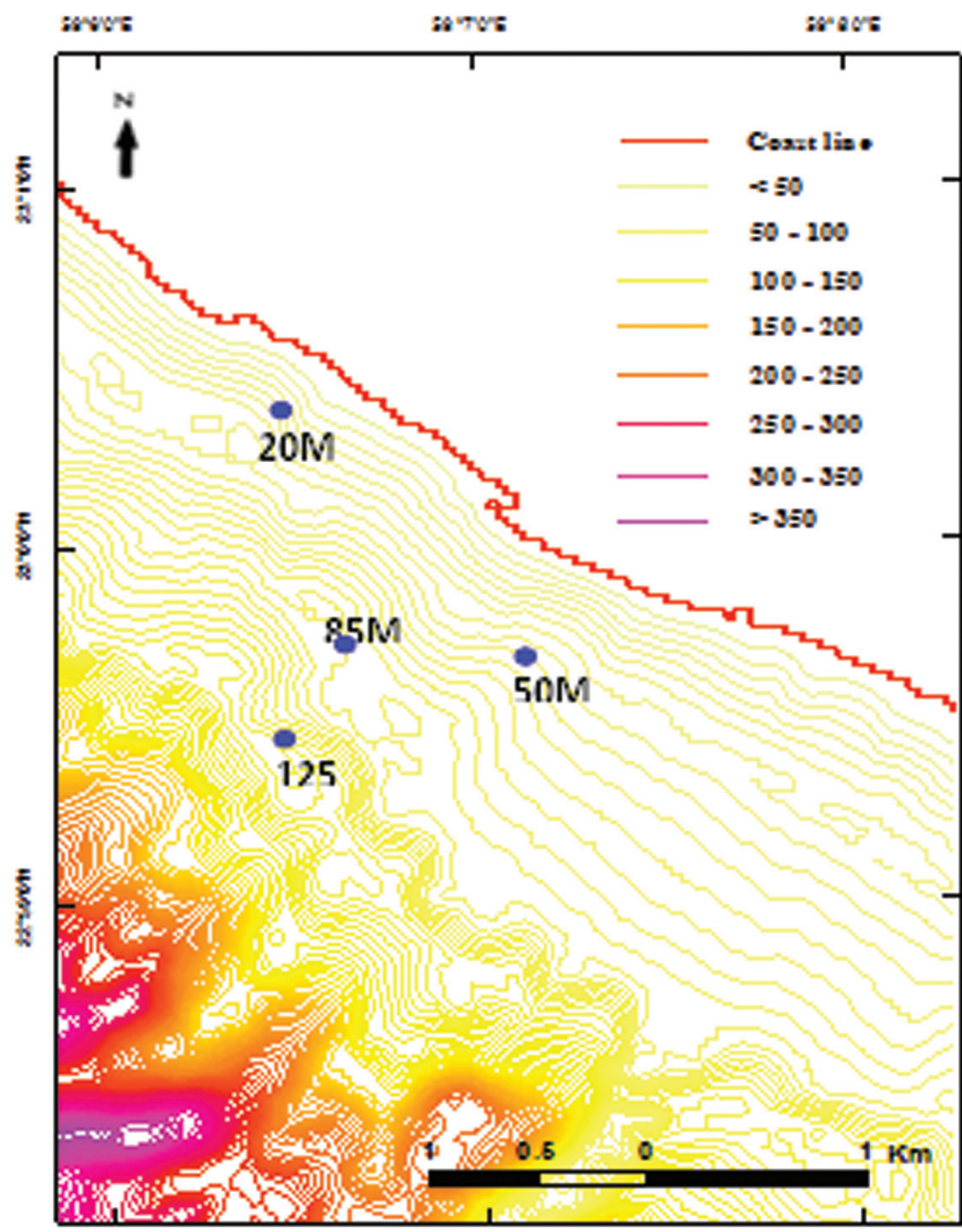

Photo (1): View from the $20 \mathrm{~m}$ level platform showing platform sequence

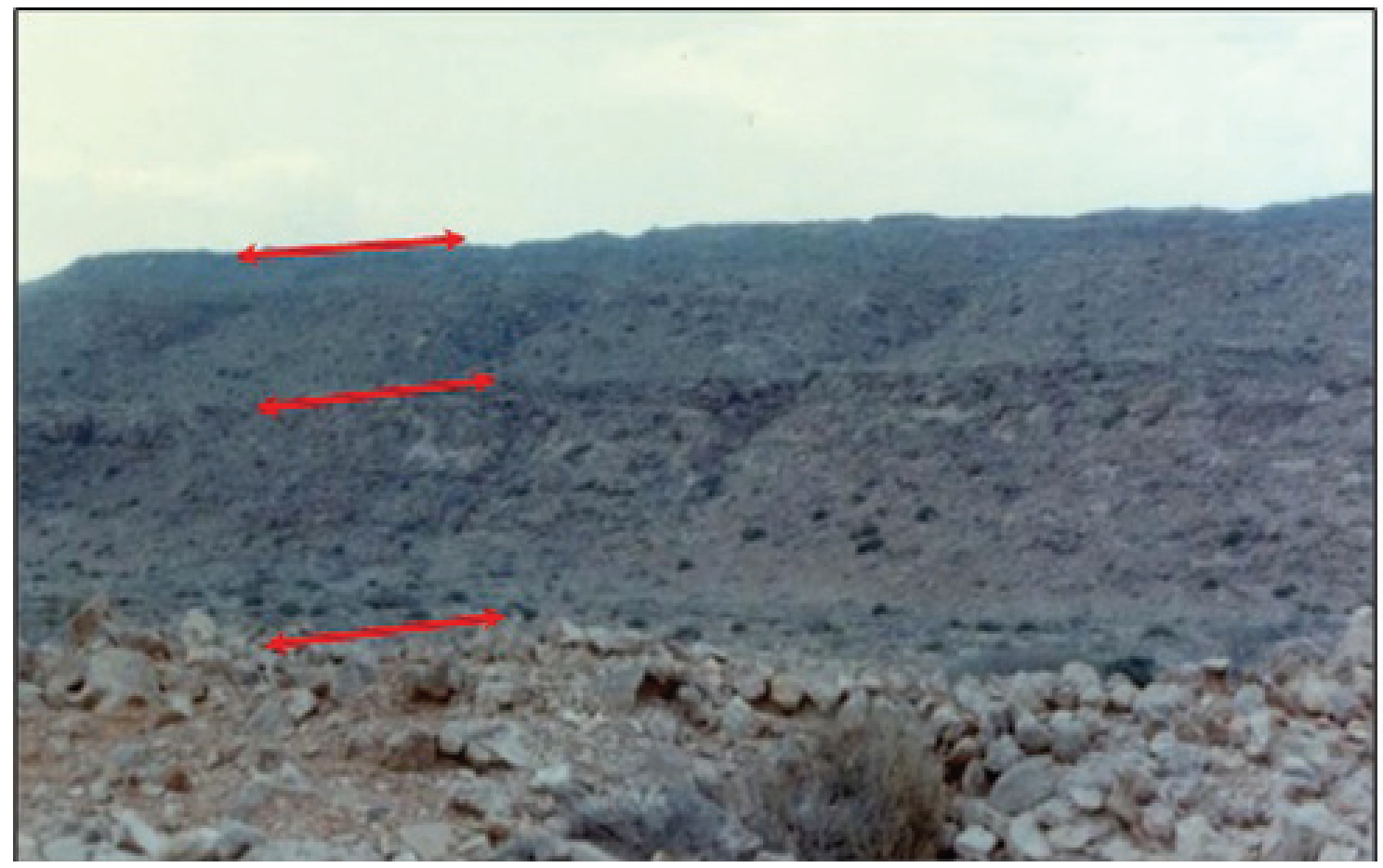


Photo (2): Small scale karst topography on the surface of the platforms

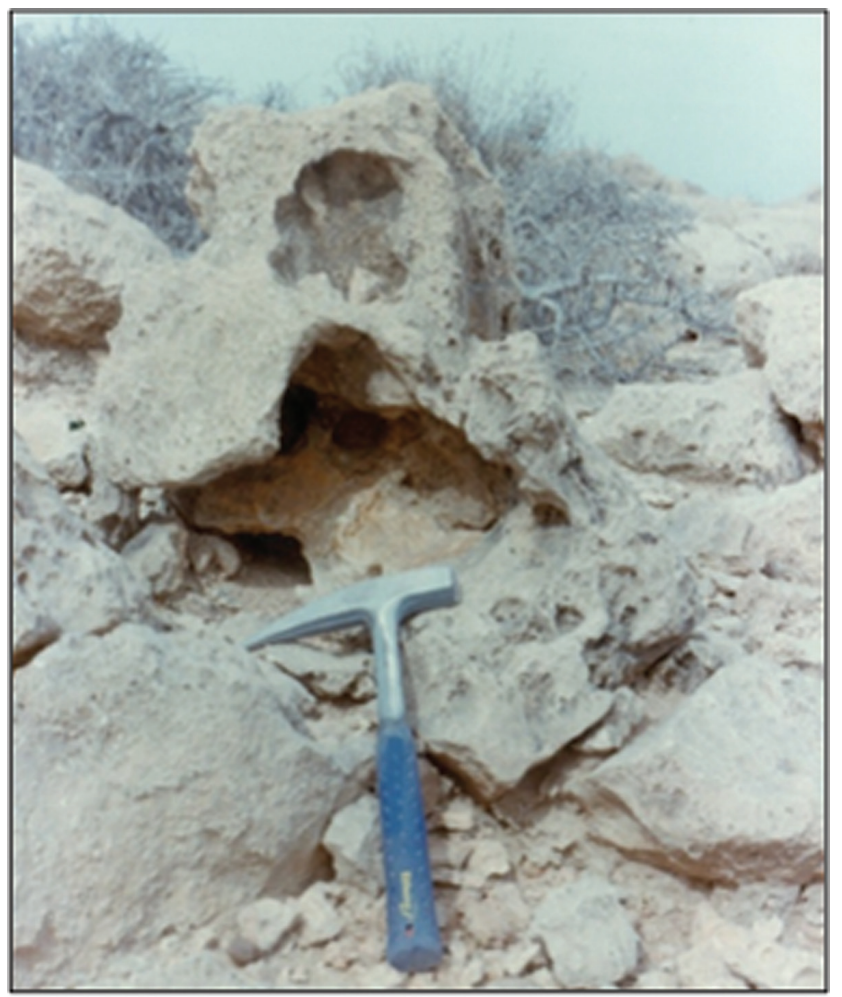

